\title{
ON THE ARCHAIC MEANING OF THE WORD FILUM IN APULEIUS
}

\section{Svetlana S. Dubova}

St. Petersburg State University (SPbSU), 7/9 Universitetskaya nab., 199034, St. Petersburg, Russia; dubovasvetlanas@gmail.com

The paper discusses how the meaning 'appearance, figure' of the Latin word filum was developed in the pre-classical writers' works and how the meaning in question was revived in the texts of later authors, especially in the writings of Apuleius. The present meaning is typical of Lucretius, as in his poem On the Nature of Things he regards bodies as an interweaving of atoms and describes them with terms from the weaving field. It was Lucretius whom Apuleius referred to speaking about the nature of daemons: fila corporum (De deo Soc. 11). The use of the word filum regarding human appearance could have developed as a metaphorical transfer from clothing to its owner. For the post-classical period writers this meaning was already unusual, and the word filum was often supplemented by the explicative words corporis or oris. The author makes an assumption that the word filum in reference to the human appearance enjoyed popularity in the post-classical literature due to its archaic color. A significant number of the same type expressions with the word filum in the given meaning (bono filo, decente filo, filo virginali etc.) are also pointing to the fact that these expressions were idiomatic.

Keywords: archaic vocabulary, Apuleius, Lucretius, Latin idioms, weaving metaphors.

As is well known, Apuleius frequently uses words in unusual meaning, either reinterpreting them in his own way or borrowing interpretations from archaic authors. Filum meaning 'appearance' in Met. 4. 23 is just a case in point. Having stolen Lucius, the ass, the robbers bring Charite into the cave:

Nec mora, cum latrones . unicam virginem, filo liberalem et, ut matronatus eius indicabat, summatem regionis, puellam mehercules et asino tali concupiscendam, maerentem et crines cum veste sua lacerantem, advehebant.

filio F, corr. $v$

"Without delay the robbers . brought one single maiden, noble-looking and, as her dress indicated, from the upper social class in this place. By Hercules, she was a girl who could inspire the desire even of an ass like me; she was mourning and pulling at her hair and clothes."

Filum is a rather widespread word. On account of its primary meaning ('thread') it can refer to a variety of objects, denoting a spider's web, lyre's strings, a wick of a candle or a span of life. Whereas in relation to any object which can be described in terms of thinness and has a certain length the word appears fairly natural, virgo filo liberalis seems peculiar, if not to say strange. The relevant meaning can be found in quite a few passages. H. Lackenbacher in ThLL classifies them under the heading "4. i. q. figura, forma, habitus, qualitas", where filum should refer to physical objects, people or speech. ${ }^{1}$ The latter usage is exemplified by a number of contexts in Cicero, who even uses filum to denote style as a complex concept (as in De or. 2. 93: Greek orators kept "the juice", sucum, of Pericles but with "a little more copious thread", paulo uberiore filo), the idea of a thread being in this

1 Lackenbacher 1926, 763.

(C) St. Petersburg State University, 2017 
case not that obvious. Still, comparing a speech to a thread is absolutely reasonable. The (un)weaving metaphor, most clearly implied in textum, presents itself: cf. "thread of a story", "le fil de la conversation", "der Faden des Gesprächs" etc.

Applying filum = forma, figura to corporeal objects is something completely different - no wonder that this use is extremely rare. In fact, it is attested only in Lucretius, and at first glance seems to have nothing in common with 'thread':

(exordia rerum)

debent ni mirum non omnibus omnia prorsum

esse pari filo similique adfecta figura (2.340-341)

"It is not surprising that (the beginnings of things) must not all be of equal composition [?] and similar shape."

The same use of filum is attested in the De rerum natura several times: formarum vestigia. volitant. subtili. praedita filo (4.88); forma quoque hinc solis debet filumque videri (5. 571); omnia. specie confusa videntur quam minui filum (5.581); ignes. mutare videntur. filum (5. 589). According to $O L D(s . v .7)$ it is the size of an object that Lucretius has in mind. Yet, it is more probable that filum as well as textura, 'texture', refers to its shape. ${ }^{2}$ Lackenbacher analyzed all the occurrences of the nouns filum and textura in the De Rerum Natura and stated the equality of these two terms. ${ }^{3}$ Indeed, throughout the poem Lucretius emphasizes the connection between atoms, their interweaving. To describe this connection Lucretius uses the words textura, nexus, contextus, textus/textum, all of which are related to the idea of weaving and binding (cf. 1. 241-247). The nature of the interweaving of atoms defines the general form of a body. The atoms of a solid body are densely tied together and their connection is hard to destroy, while the structure of a soul is completely different, braided from extremely small particles (tenui textura: 3. 209) and therefore exceptionally mobile. That means that the way of connection between the atoms influences how something looks, so filum is both a part of inner structure and outer form. In Lucretius' philosophy the whole world is by nature of a fabric, whose threads can be densely attached to each other or intertwine loosely and let the air come through easily. The poem is full of weaving images, as J. M. Snyder observes, stressing, in particular, that the atoms themselves are called exordia, the term originally referring to the warp threads. ${ }^{4}$ Thus, filum takes its legitimate place among other weaving metaphors ${ }^{5}$ describing complex bodies.

Since both in the De Rerum Natura and in numerous descriptions of a literary style (as in Cicero) filum keeps the meaning 'thread', it is best to agree with Lackenbacher that there is no need to postulate two words filum with different etymologies. ${ }^{6}$ The latter as-

2 Although Lucretius uses filum instead of non-metrical magnitudo to indicate size when he describes the way people perceive heavenly bodies (examples in: Bailey 1947, 1411).

3 Lackenbacher 1922, 127-137. Bailey $(1947,860)$ gives three meanings for filum in Lucretius: 'shape', 'texture', 'size'.

4 Exordium was mostly used in its general sense 'beginning', but a significant number of weaving metaphors in Lucretius open a possibility to interpret exordium as one of them: Snyder 1983, 38-40; Marković 2008, 117.

5 Cf. Bailey 1947, 860.

6 Lackenbacher 1922, 132. 
sumption is made by Walde ${ }^{7}$ and Ernout/Meillet. ${ }^{8}$ Both dictionaries suggest deriving $f i-$ lum = 'figure, appearance' from the same root as in fingo ( ${ }^{*}$ figslom). According to Ernout and Meillet it could have developed from the meaning 'line' - just as ligne functions in French (cf. 'garder la ligne'; 'les lignes d'un visage'). Still, the idea of a thread as something thin and long is present in French metaphoric ligne, but absent in Lucretius. Semantically filum is drastically different from the words denoting a thread in modern languages. It was nicely put into words by C. Giussani in his edition of Lucretius: "Il senso metaforico di filum in latino si discosta dall'italiano: per noi il filo è sopratutto ciò che tiene unita una serie; in latino è piutosto il tessuto, il modo e la materia onde una cosa è costituita". Moreover, M. de Vaan believes the initial $f$ in the words filum and fingo to have come from different consonants. ${ }^{10}$ All that gives credence to the idea that in Latin the word filum was used metaphorically without losing its primary meaning.

Apart from description of Charite's appearance in the Metamorphoses, Apuleius also uses filum when he explains the nature of daemons in his philosophical oration On the God of Socrates. Here the use of this word clearly reminds of Lucretius, and it is hardly a coincidence that filum with the same meaning appears right after Apuleius' commentary on one of the passages of the De R.N.:

Quod si nubes sublime volitant, quibus omnis et exortus est terrenus et retro defluxus in terras, quid tandem censes daemonum corpora, quae sunt concretio multo tanta subtilior? Non enim ex hac faeculenta nubecula et umida caligine conglobata, sicuti nubium genus est, sed ex illo purissimo aeris liquido et sereno elemento coalita eoque nemini hominum temere visibilia, nisi divinitus speciem sui offerant, quod nulla in illis terrena soliditas locum luminis occuparit, quae nostris oculis possit obsistere, qua soliditate necessario offensa acies inmoretur, sed fila corporum possident rara et splendida et tenuia usque adeo ut radios omnis nostri tuoris et raritate transmittant et splendore reverberent et subtilitate frustrentur (De deo Socr. 11).

"But if the clouds fly aloft, all of which originate from the earth and then go back down to it, what should you at last think about the bodies of daemons, whose formation is much more attenuated? For they are not conglobed from feculent overcast and humid gloom, as the clouds originate, but they are formed from the purest liquid of air and the serene element. And therefore they are not easily visible to any human, unless they present their image by divine command, because the place of light in them is not occupied by any earthly solidity which could impede our eyes, as our sight would necessarily linger when opposed by this solidity. But they possess the bodily texture so rare, splendid and attenuated, that they pass through all rays of our gaze by their rarity, reflect them by their splendor, and delude them by their subtlety.'

The idea of filum as the term uniting the atomic structure and the nature of a body is here quite apparent. Still, compared to the above examples, filum in reference to human appearance is somewhat unexpected. Indeed Cicero used it to denote style, but this is not present in other writers of the classical period. ${ }^{11}$ The first author who applies filum to a human is Plautus:

7 Walde ${ }^{2} 1910,291$.

${ }^{8}$ Ernout, Meillet ${ }^{3} 1951,418$.

9 Giussani 1896, 199.

10 De Vaan 2008, 220-221, cf. Walde, Hofmann 1938, 497.

11 Though later filum referring to speech became quite popular. Aulus Gellius who notably sympathized with Cicero wrote that Varro had attributed some disputable comedies to Plautus as they went with this comedian filo atque facetia sermonis (3. 3. 3), and Herodotus composed the story about Arion vocum filo 
COC. Haecin tua est amica, quam dudum mihi

te amare dixti, quom obsonabas? LYS. Non taces?

COC. Satis scitum filum mulieris (Pl. Merc. 753-755).

"Cook. Is this your sweetheart, whom a while ago you told me you were in love with, when you were buying the provision? Lysimachus. Won't you close your mouth? Cook. The woman looks pretty nice."

Since the cook sees Dorippa for the first time, filum should refer to the appearance, whether it is the face or the figure in general. ${ }^{12}$ The face was meant by Lucilius, if we are to believe Nonius: filum non malum (816, Non. 489 Lindsay), which the grammarian provides with an explanation oris liniamentum. ${ }^{13}$ However, strictly speaking neither Lucilius (since the context is lacking ${ }^{14}$ ) nor Plautus informs about the exact meaning. Perhaps more informative is Varro, when he explains the concept of similarity: eo porro similiores sunt qui facie quoque paene eadem, habitu, corporis filo: itaque qui plura habent eadem, dicuntur similiores (Ling. 10, 4, 7).

After the time of Varro filum = 'appearance' is used by Aulus Gellius and Apuleius, both well-known for their penchant for archaic vocabulary. As claimed by Gellius, Pythagoras determined the moral qualities of young men by evaluating their appearance: de oris et vultus ingenio deque totius corporis filo atque habitu (1. 9. 2). Here corporis filo looks very much like a direct borrowing from Varro. ${ }^{15}$ Another occurrence of such filum in Noctes Atticae (14. 4. 2) proves that it was already largely artificial and probably had an

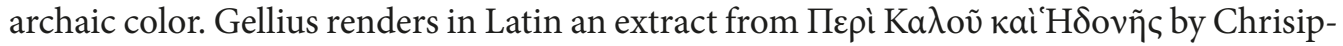
pus, which he considers exceptionally well written. It deals with how artists usually depict the image of Iustitia, namely: forma atque filo virginali. Since Chrysippus wrote condigne mehercule et condecore, Gellius translation should itself be most elegant. This must be why he prefers virtually archaic filum to a more colloquial word. It remains to guess, how this could sound in Chrysippus' now lost treatise: there is nothing like filum with the given meaning in Greek ( $\nu \tilde{\eta} \mu \alpha$, $̋ \varphi \alpha \sigma \mu \alpha$, $̋ \varphi \eta$ etc. never mean 'appearance').

Against the background of the occurrences of filum meaning the way that someone or something looks, Petr. Sat. 46.3 particularly stands out, since it refers not to the physical but to the moral qualities: ingeniosus est et bono filo, etiam si in aves morbosus est. ${ }^{16}$ Echion, one of Trimalchio's guests, tells that about his cicaro. ${ }^{17}$ Bono filo resembles an idiom: in

tereti et candido (16. 19. 1). The style of a speech was called filum by Ausonius (336. 67), Symmachus (Ep. 1. 1. 2) and Macrobius (Sat. 5. 13. 11; 6. 3. 9). All of them probably borrowed from Cicero.

12 It seems more likely that the general appearance is meant: the cook makes a remark on the woman without going into details. Cf. Dunsch 2000, 285. A. Ernout takes filum here as a word referring to the woman's slenderness: “C'est un assez beau brin de fille" (Ernout ${ }^{8} 1992,141$ ).

${ }_{13}$ E. H. Warmington seems to regard filum in Lucilius as a colloquialism, cf. his translation: "it's not a bad phiz" (Warmington 1938, 305), also "keinen schmollenden Flunsch" (Krenkel 1970, 449).

14 The verse is $\langle$ Tu $>$ surge, mulier, duc te, filum non malum, though some editors claim that it is incomplete and the reading is doubtful, see Warmington 1938, 305, n. d. F. Charpin ignores Nonius' explanation in his translation: "une belle silhouette de fille". In the complementary notes he states that filum can refer to facial features, as well as to the general appearance (Charpin 1991, 21, 179).

15 Most editors in Varro's passage take corporis with habitu and put a comma between corporis and filo, but Gellius' text proves that these words should be taken together.

16 G. Schmeling's commentary on this passage is rather laconic: "made of good stuff" (Schmeling 2011, 193).

17 Probably his slave boy, not his son: Schmeling 2011, 193; Gaide 1993, 386-387. Trimalchio refers to his pet slave as cicaro (71. 11). Furthermore, Echion's Primigenius is destined to become Agamemnon's 
fact, filum repeatedly appears in the ablative, ${ }^{18}$ accompanied by a positive connotation adjective (in late Latin cf. ex. gr. Arn. Adv. nat. 3. 13. 1: filo humano; Amm. Marc. 14. 11. 28: decente filo corporis; Iul. Val. 1. 7: suo modo et filo pulcherrimus; 2 . 26: filo oris et aliquorum membrorum situ admirabilis ${ }^{19}$ ). Echion is a centonarius; if he works in the rag trade, ${ }^{20}$ he could use professional jargon. ${ }^{21}$ But, what is more, he tries to talk stylishly, using expressions he considers urbane (such as in alqd. morbosum esse; notably, he starts with: oro te, melius loquere: 45. 1). A rather sophisticated bono filo could be one of them, and the comic effect would be stronger, if Echion would use the metaphoric filum in an improper sense (consider that he praises the boy's aptitude for learning ${ }^{22}$ ).

It seems natural that people who wear good clothes look like they 'are of good stuff'. Accordingly, I propose to explain the uncommon metaphorical meaning of filum ('thread' = 'appearance') in Apuleius and beyond as a transfer from clothing to its owner. Likewise, Fronto (another lover of archaisms) compares speech to fabric: potius ut in conpositionis structuraeque mollitia sit delictum quam in sententia inpudentia: vestem quoque lanarum mollitia delicatam esse quam colore muliebri, filo tenui aut serico, purpuream ipsam, non luteam nec crocatam (Ad M. Caes. 1. 8. 3 = 1. 118 Haines). Much like a good oratory, a person can prove to be "of a finely woven thread". Needlework provides, of course, rich material for description of various human activities. One can give numerous examples from languages other than Latin of idiomatic expressions like bono filo et sim. in reference to a person: “не лыком шит", “одним лыком шиты” in Russian ('sewn not with bast fibre' and 'sewn with the same bast fibre', meaning 'not born yesterday' and 'acting in the same manner as someone else'), "cut from the same cloth" in English, "cousu d'or" in French ('sewn with gold threads', i.e. 'rich'). This metaphorical filum, natural for Plautus and Lucilius, by the time of Apuleius became a vivid idiom slightly tinged with an archaic hue. ${ }^{23}$ In this quality it continued its existence in the Latin literature at least till the end of the $4^{\text {th }}$ century AD.

\section{References}

Bailey C. (ed., transl., comm.) Titi Lucreti Cari De Rerum Natura libri sex. Oxford, Clarendon Press, 1947. Charpin F. (ed., transl.) Lucilius, Satires. Tome III. Paris, Les Belles Lettres, 1991.

De Vaan M. Etymological Dictionary of Latin and the other Italic Languages. (Leiden Indo-European Etymological Dictionary Series 7). Leiden and Boston, Brill, 2008.

servulus, and he lives at a farm where he definitely has some work to do (quidquid illi vacat, 46. 3).

18 The exceptions are De deo Socr. 11, and Arnob. Adv. nat. 6. 13. 4: artifices omnes. certabant filum capitis prostituti Cythereia in simulacra traducere.

19 C. Weyman $(1893,345)$ noticed these and many other correspondences between Apuleius and Iul. Valerius Polemius. That the latter borrowed from the former is fairly obvious.

20 Echion's profession is a subject of debate. There are two main possibilities: Echion is either a firefighter (OLD s. v.; Schubert 1998, 173) or a rag-and-bone man (Gaide 1993, 387; Krauss 1928, 162). On Echion's profession see Schmeling 2011, 181, on the centonarii in general see Liu 2009.

21 One can say that we tend to forget the literal meaning and origins of idioms, so it may not be important that a centonarius uses a peculiar expression with the word filum. However, it is hard to believe that Petronius chose this rare idiom for no reason.

22 This was disregarded by Forcellini who states $s . v$. that filum here, as in most cases, refers to appearance.

23 It is worth noting that the majority of writers of the post-classical period use the word filum in the discussed meaning with a specifying noun in the genitive case so the reader could easily see that the author is referring to the outward appearance: facial features or body shape. These details do not seem to be a necessity for Plautus and Lucilius. 
Dunsch B. (comm.) Plautus' Mercator: a Commentary. PhD Thesis, University of St. Andrews, 2000.

Ernout A. (ed., transl.) Plaute, Tome IV: Maenechmi - Mercator - Miles Gloriosus. Paris, Les Belles Lettres, ${ }^{8} 1992$.

Ernout A., Meillet A. Dictionnaire étymologique de la langue latin. Paris, Librairie C. Klincksieck, ${ }^{3} 1951$.

Gaide F. Primigénius et les oiseaux (Pétron, Sat. 46). Latomus 1993, 52, 2, 386-388.

Giussani C. (ed., comm.) T. Lucreti Cari De Rerum Natura libri sex. Vol. I. Torino, Ermanno Loescher, 1896.

Krauss F. B. The Human Element in Latin Inscriptions. The Classical Weekly 1928, 21, 161-163.

Krenkel W. (ed., transl.) Lucilius: Satiren. Zweiter Teil. Berlin, Akademie-Verlag, 1970.

Lackenbacher H. Filum. Thesaurus Linguae Latinae 1926, 6, 1, 760-764.

Lackenbacher H. Zur Etymologie von filum. Glotta 1922, 12 (1/2), 127-137.

Liu J. Collegia Centonariorum: The Guilds of Textile Dealers in the Roman West. Leiden and Boston, Brill, 2009.

Marković D. The Rhetoric of Explanation in Lucretius' De rerum natura. Leiden and Boston, Brill, 2008.

Schmeling G. with the collaboration of Setaioli A. (comm.) A Commentary on the Satyrica of Petronius. Oxford, Oxford University Press, 2011.

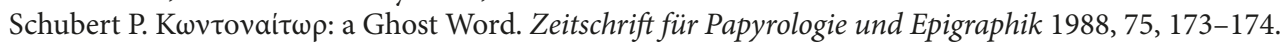

Snyder J. M. The Warp and Woof of the Universe in Lucretius' “De Rerum Natura”. Illinois Classical Studies $1983,8,1,37-43$.

Walde A. Lateinisches Etymologisches Wörterbuch. Heidelberg, Carl Winter’s Universitätsbuchhandlung, ${ }^{2} 1910$.

Walde A., Hofmann J. B. Lateinisches Etymologisches Wörterbuch. Heidelberg, Carl Winter's Universitätsbuchhandlung, 1938.

Warmington E.H. (ed., transl.) Remains of Old Latin, Volume III: Lucilius; The Twelve Tables. Cambridge, Massachusetts, Harvard University Press, 1938.

Weyman C. Studien zu Apuleius und seinen Nachahmern. SBAW 1893, 2, 321-392.

For citation: Dubova S.S. On the Archaic Meaning of the Word filum in Apuleius. Philologia Classica 2017, 12(2), 136-141. https://doi.org/10.21638/11701/spbu20.2017.203

\section{ОБ АРХАИЧЕСКОМ ЗНАЧЕНИИ СЛОВА FILUМ У АПУЛЕЯ}

Светлана Сергеевна Дубова

Санкт-Петербургский государственный университет, Российская Федерация, 199034, Санкт-Петербург, Университетская наб., 7-9; dubovasvetlanas@gmail.com

В статье рассматривается неочевидное метафорическое значение «внешности» у латинской лексемы filum (букв. «нить»). Данная семантика регистрируется у авторов доклассического периода (Плавт, Лукреций), а затем у поздних, в особенности же - у Апулея. Употребление filum применительно к внешнему виду человека предположительно развилось из метафорического переноса с одежды на ее обладателя. Для писателей I-II вв. н. э. оно уже не было привычным, требуя пояснений (filum corporis или oris). Популярность filum по отношению к внешности в послеклассической литературе, вероятно, вызвана архаическим колоритом. Однотипность сочетаний с filum в данном значении (bono filo, decente filo, filo virginali и т. д.) свидетельствует об их идиоматическом характере.

Ключевые слова: архаическая лексика, Апулей, Лукреций, латинские идиомы, метафоры ткачества.

Received: 09.07.2017

Final version received: 01.10.2017 